\title{
$\therefore$ Formulation of Natural Elite Dye Remover from Textile Effluent
}

\author{
IJCRR \\ Section: Healthcare \\ ISI Impact Factor \\ (2019-20): 1.628 \\ IC Value (2019): 90.81 \\ SJIF (2020) $=7.893$ \\ (ब) 8 ( 8 \\ Copyright@IJCRR
}

\section{Sri Sowmitha Ramesh, Komala Devi S,Tamilselvi S, Moni Philip Jacob K, Ragamathi S, Rajaseetharama S, Jeyavel Karthick P, Pavithra MKS}

Department of Biotechnology, Bannari Amman Institute of Technology, Sathyamangalam, Erode - 638401, Tamil Nadu, India.

\section{ABSTRACT}

Introduction: The dyes used in the textile industry poses a major problem to wastewater sources and the environment. Common ways of wastewater treatment containing dyes include adsorption, sedimentation, chemical analysis, chemicoagulation, biological methods, and advanced oxidation procedures.

Objective: To produce the papaya seed, banana pith and pineapple peel powder and treat textile synthetic wastewater with these natural coagulants.

Methods: Papaya seed, Banana pith and Pineapple peel were dried at a particular temperature and ground into powder. Coagulation and flocculation tests were carried out using the jar test apparatus in which $500 \mathrm{~mL}$ of raw water sample was treated with different concentration of natural coagulants. BOD and COD were determined, FTIR analysis was made to know the functional group of natural coagulants which is responsible for efficient dye removal.

Results: The turbid remaining vs. coagulant dosage graph has been plotted. The treated textile wastewater sample is tested for the presence of BOD; initially, the value was $337.25 \mathrm{mg} / \mathrm{L}$ with dark blue colour and after 5 days of incubation the colour reduces and brownish precipitate forms with a value of $185.43 \mathrm{mg} / \mathrm{L}$. Treated textile wastewater is tested for the presence of the chemical oxygen demand, after 2 hours of digestion, titration is carried out, which showed the change in bluish-green colour to red colour. The result indicates initially COD value as $480 \mathrm{mg} / \mathrm{L}$ which is reduced to $323 \mathrm{mg} / \mathrm{L}$.

Conclusion: The FTIR results showed the presence of potential functional group which is responsible for dye removal. The initial value of $B O D$ and COD was reduced from its original value. Hence, natural coagulants play a potential role in the treatment of Dyes in textile effluent.

Key Words: Papaya seed, Banana pith, Pineapple peel, Natural coagulant, Textile colouring water

\section{INTRODUCTION}

Textile industries produce a huge amount of coloured wastewater which contains pollutants such as heavy metals, chemicals, and various dyes. Waterbody pollution is considered as a serious life threat environmentally across the globe. Discharge of untreated wastewater to water bodies causes various types of problems to the marine and terrestrial ecosystem. ${ }^{1,2}$ Throughout year Textile industries release massive amount to wastewater, these effluents are highly resistant to $\mathrm{pH}$, light, microbial attack and this makes them stable for a longer period in environment. ${ }^{2,3}$ In India, around $80 \%$ or $1,30,000$ tons of dyes consumes in the textile industry due to elevated demand for cotton and polyester. These harm- ful dyes effectively create a bad impact on photosynthetic function in plants, due to penetration of low light and consumption of oxygen creates a huge impact on aquatic life and also decreases the capacity of oxygen and food production in algae. ${ }^{1,4,5}$

The reuse of textile wastewater, efficient treatment is necessary to achieve water scarcity. Globally several studies have been undergone for the treatment of textile dye waters through Advanced oxidation with biological oxidation, Granular activated carbons, Coagulation-electro-oxidation, Adsorbent, Wet oxidation, Fenton's reagent. ${ }^{6}$ The mentioned techniques work in the mechanism of production of hydroxyl free radical (HO) that destroys the chemical bond of dyes

\section{Corresponding Author:}

Tamilselvi S, Department of Biotechnology, Bannari Amman Institute of Technology, Sathyamangalam, Erode - 638401, Tamil Nadu, India; Email: TAMILSELVIS@bitsathy.ac.in

ISSN: 2231-2196 (Print)

Received: 30.09 .2020
ISSN: 0975-5241 (Online)

Revised: 06.11 .2020
Accepted: 14.12 .2020
Published: 16.02 .2021 
and thus lowering the concentration value of BOD and COD. Another most effective technique used for the treatment is Membrane-filtration. However, these conventional methods have some of the disadvantages such as high cost, more number of by-products, generation of more sludge, high cost of operating, limited to pilot scale. So far, Synthetic conventional techniques have certain disadvantages researchers done another way of treatment using inorganic coagulants. Aluminium sulfate, ferric chloride, poly aluminium chloride effectively acts as the remover of dyes in wastewater, But still, there are certain potential causes of serious health issues. Due to drawbacks of synthetic conventional techniques and inorganic coagulants paves a way for the another safer, eco-friendly techniques for the treatment of wastewater is that Natural coagulants. ${ }^{78}$ Natural coagulants can be extracted from the plants, animals and microorganisms. ${ }^{9}$ Natural coagulants satisfy the drawbacks of synthetic treatments, in contrast, it produces a very limited amount of sludge production and also higher nutritional sludge value. ${ }^{8,10}$

In the present study, we explore the effectiveness of natural coagulants of plant ${ }^{3}$ and non-plant based and showed the results of the effectiveness of three combinations of fruit waste powders (Plant-based) such as papaya seed, ${ }^{6,11} \mathrm{Ba}-$ nana pith and Pineapple peels that are mixed with the certain ratio which acts as natural coagulants. These combinations of different natural coagulants owing to the multifunctional characteristics are facilitated by polyelectrolyte interactions, which form the precipitation of synthetic dyes and heavy metals present. Carica papaya (Papaya) is a tropical fruit found in Asia and South America. Papaya seeds have been used to treat turbid water can be used to treat turbid water with faecal bacteria. Anana scomosus (Pineapple) also a tropical fruit found in Costa Rica are found in South America. ${ }^{12,13}$ Due to the production of adsorbent Pineapple used for removal of dye and also prevents disposal cost. ${ }^{7}$ Musa (Banana) a tropical fruit widely found in Tamil Nadu and Kerala. Banana pith is a natural polyelectrolyte which is acting as a good natural absorbent in the treatment of textile colouring water. ${ }^{5}$ From the present research of this combination samples, used for the treatment of textile synthetic wastewater and then results were confirmed and characterized using intensity difference, the effect of $\mathrm{pH}$ and coagulant dosage, $\%$ of BOD and COD. ${ }^{7,8}$

\section{MATERIALS AND METHODS}

\section{Collection of water sample and preparation}

Textile coloring water was collected from the RATHI TEX DYEING manufacture situated in the Tirupur district, Tamil Nadu.

Papaya, Banana pith and Pineapple were purchased from the local market Annur locality. Desired portions from the fruits were separated as such Papaya seeds, Banana pith and Pineapple peels were washed thoroughly using distilled water and dried at a temperature of Papaya seeds $\left(110^{\circ} \mathrm{C}\right.$ for 10 hours), Banana Pith ${ }^{4}\left(60^{\circ} \mathrm{C}\right.$ for 6 hours) and Pineapple peels ( $105^{\circ} \mathrm{C}$ for 2 to 3 hours), ground and then sieved to obtain powder in the mesh size of $10-20 \mathrm{~mm}$. Then the powders were stored in the airtight containers for further use.

\section{Coagulation Test}

\section{Jar Test}

Coagulation and flocculation tests were studied using a jar test apparatus. Three Jars were filled with $500 \mathrm{~mL}$ of the raw water sample. The $\mathrm{pH}$ was adjusted using $\mathrm{NaOH}$ or sulfuric acid to different $\mathrm{pH}$ such as 5.0, 5.5, 6.0, 6.5, 7.0, and 7.5. Different concentrations of powdered coagulant samples were added to each jar containing raw water samples of 5 , 10,15 and $20 \mathrm{mg} / \mathrm{ml}$. Each jar rapidly mixed at $100-150 \mathrm{rpm}$ for 5 minutes. Later, the stirring speed was reduced to 25 $30 \mathrm{rpm}$ and mixing was continued for 15-20 minutes. The mixers were turned off and allowed flocs to settle for 3045 minutes. The final residual turbidity in each sample was measured.

\section{Evaluation of Biological Oxygen Demand}

$100 \mathrm{~mL}$ raw water sample was filled in a BOD bottle without making air bubbles. $2 \mathrm{~mL}$ of Manganese sulphate and Alkaliiodide azide reagent were inserted by pipette just below the surface of the water. Formation of a brownish precipitate indicates the presence of oxygen. Finally, $2 \mathrm{~mL}$ of concentrated sulphuric acid was added and closed. The bottle was incubated for 5 days. Later, the titration was carried out using sodium thiosulphate which changes the colour to pale yellow and $2 \mathrm{~mL}$ of starch was titrated and changes the colour to blue and finally, readings were noted.

\section{Evaluation of Chemical Oxygen Demand}

The raw water samples were diluted to 1:250 ratios, from the diluted sample $2.5 \mathrm{~mL}$ was taken and prepare blank to which $1.5 \mathrm{~mL}$ of potassium dichromate and $3.5 \mathrm{~mL}$ of sulphuric reagent was added to the COD tube. Now, each turbid water samples of $2.5 \mathrm{~mL}$ were taken in different tubes and $1.5 \mathrm{~mL}$ of potassium dichromate and $3.5 \mathrm{~mL}$ of sulphuric reagent was added to each tube and subjected to COD digester for 150 ${ }^{\circ} \mathrm{C}$ for 20 minutes. After attaining strong heating point the tubes were left at $150^{\circ} \mathrm{C}$ for 2 hours. In the end, the titration was carried out using 0.1N FAS, 2 drops of ferroin indicator, which changes the green to red in the colour end product to find the difference in the intensity of the sample and graph were plotted.

\section{Statistical Analysis}

All the experiments were performed in triplicates. The statistical significance was measured using one way ANOVA. 
The 'P-value' was found to be $<0.05$, which is considered to be significant ${ }^{14}$.

\section{RESULTS}

\section{Preparation of three different fruit powders}

Papaya seed was collected and oven-dried for 2 days at 106 ${ }^{\circ} \mathrm{C}$ and ground into a powder that contains $10 \mathrm{~g}$ totally and stored at desiccators. Banana pith or stem was collected and oven-dried for 2 days at $62^{\circ} \mathrm{C}$ and ground into a fine powder that contains $12 \mathrm{~g}$. Pineapple peel was collected and ovendried for 4 days to remove the complete moisture at $112^{\circ} \mathrm{C}$ and ground into a powder form that weighs about $20 \mathrm{~g}$ and stored at containers. All these powders are taken with different grams to proceed with various analysis which can be utilized as a natural coagulant to treat the textile wastewater.

\section{FTIR analysis}

FTIR analysis is done to observe functional groups that are present in natural coagulants. The FTIR spectra of papaya seed powder are presented in Figure 1, Banana pith are presented in Figure 2, Pineapple peel are presented in Figure 3 . From the results papaya seed has a highest sharp peak at $2923.17 \mathrm{~cm}^{-1}$, indicating the presence of $\mathrm{N}-\mathrm{H}$ stretching, and a peak indicated the presence of symmetrical and asymmetrical C-H stretching at $2923.17 \mathrm{~cm}^{-1}$ and 2853.73 $\mathrm{cm}^{-1}$. Banana pith has the highest sharp peak at $1016.50 \mathrm{~cm}^{-1}$ and $1619.27 \mathrm{~cm}^{-1}$ indicating the presence of $\mathrm{C}=\mathrm{O}$ stretching. Pine apple peel has a highest sharp peak at $1047.36 \mathrm{~cm}^{-1}$ and $3331.12 \mathrm{~cm}^{-1}$ indicating the presence of $\mathrm{C}=\mathrm{O}$ stretching and $\mathrm{O}-\mathrm{H}$ stretching bonds. Thus the above results indicate that different functional groups are present in the samples that contain potential poly-electrostatic interaction.

\section{Coagulation and flocculation test by the jar test method}

Each jar contains water sample was treated with different concentrations of natural coagulants ${ }^{11}$ papaya seed, banana pith and pineapple peel powders with help of mechanical agitation the formation of the floc was developed and leads to dye removal. ${ }^{12}$ The turbid remaining vs. coagulant dosage graph has been plotted in Figure 4, Figure 5 And Figure 6 respectively.

From the above results $8 \mathrm{mg}$ of papaya seed sediment 9.6 $\mathrm{mg} / \mathrm{L}, 13 \mathrm{mg}$ of banana pith sediment $5.7 \mathrm{mg} / \mathrm{L}$ and $12 \mathrm{mg}$ of pineapple peel sediment $6.1 \mathrm{mg} / \mathrm{L}$ of dye in the treated wastewater. The above three sample combinations were mixed and used for treating the textile wastewater. ${ }^{13}$

\section{Biological Oxygen Demand (BOD)}

The treated textile wastewater sample is tested for the presence of BOD; initially, the value was $337.25 \mathrm{mg} / \mathrm{L}$ with dark blue colour and after 5 days of incubation the colour reduces and brownish precipitate forms with a value of $185.43 \mathrm{mg} / \mathrm{L}$. Thus the reduction of BOD in the sample indicates the efficient role of natural coagulants in (Figure 7).

\section{Chemical Oxygen Demand (COD)}

Treated textile wastewater is tested for the presence of the chemical oxygen demand, after 2 hours of digestion, titration is carried out, which showed the change in bluish-green colour to red colour. The result indicates initially COD value as $480 \mathrm{mg} / \mathrm{L}$ which is reduced to $323 \mathrm{mg} / \mathrm{L}$ (Figure 8).

\section{DISCUSSION}

The results of FTIR analysis showed the presence of potential functional groups present in the natural coagulants which are responsible for the removal of dye concentration in wastewater. ${ }^{9,10}$ The determination of BOD and COD level for the treated wastewater reveals the natural coagulants decreased the value to $185.43 \mathrm{mg} / \mathrm{L}$ and $323 \mathrm{mg} / \mathrm{L}$ respectively. ${ }^{13,14}$ Thus the present study concludes, the removal of colour dye from textile wastewater is attained by treating with the combination of three different fruit wastes such as papaya seeds, banana pith and pineapple peel powders in the concentration of $8 \mathrm{mg}, 13 \mathrm{mg}$, and $12 \mathrm{mg}$ respectively, which acts natural coagulants and harmless to living organisms (Table 1 and 2).

\section{CONCLUSION}

Removal of dye from textile effluent was confirmed when natural coagulant gave the decreased value of $185.43 \mathrm{mg} / \mathrm{L}$ BOD and $323 \mathrm{mg} / \mathrm{L}$ COD level. FTIR results ensure the presence of functional groups which are responsible for dye degradation. The concentration of natural coagulants papaya seeds, banana pith and pineapple peel powders found in $8 \mathrm{mg}, 13 \mathrm{mg}$, and $12 \mathrm{mg}$ respectively.

\section{ACKNOWLEDGEMENT}

We wish to express sincere gratitude to Bannari Amman Institute of Technology for providing facilities for the successful completion of research work.

Author Contribution: Sri Sowmitha Ramesh \& Komala Devi S performed the work, Moni Philip Jacob K, Rajaseetharama S \& Jeyavel Karthick P performed the collection of samples and BOD, COD analysis and wrote the manuscript, Ragamathi S \& Pavithra MKS performed and interpreted the FTIR data, Tamilselvi S guided the work, prepared and reviewed the manuscript.

Conflict of Interest: The authors declare that there are no conflicts of interest. 
Source of Funding: The authors declare that there are no funding sources to carry out this work.

\section{REFERENCES}

1. Asrafuzzaman M, Fakhruddin ANM, Hossain AM. Reduction of turbidity of water using locally available natural coagulants. Int J Microbio 2011; 63(2):189-92.

2. Dasgupta J, Sikder J, Chakraborty, Curcio S, Drioli E. Remediation of textile effluents by membrane-based treatment techniques: A state of the art review. J Envt Man 2015; 147:55-72.

3. Vijayaraghavan G, Sivakumar T, Vimal Kumar A, Application of plant-based coagulants for wastewater treatment. Int J Adv Engg Res Stud 2011; 1:88-92.

4. Kakoi B., Kaluli JW, Ndiba P, Thiong'o G. Banana pith as a natural coagulant for polluted river water. Ecol Eng 2016; 95:699-705.

5. Solanki M, Suresh S, Das SN, Shukla K. Treatment Of Real Textile Wastewater Using Coagulation Technology. Int J Chem Tech Res 2013; 5(2):610-615.

6. Selvanathan N, Subki NS. Dye absorbent by pineapple activated carbon. J Engg App Sci 2015;10(20):9476-9480.

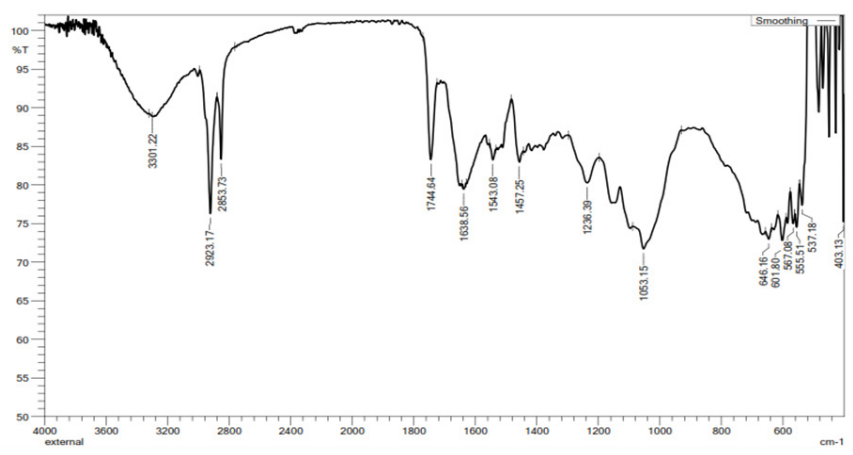

Figure 1: FTIR of the functional groups present in papaya seed.

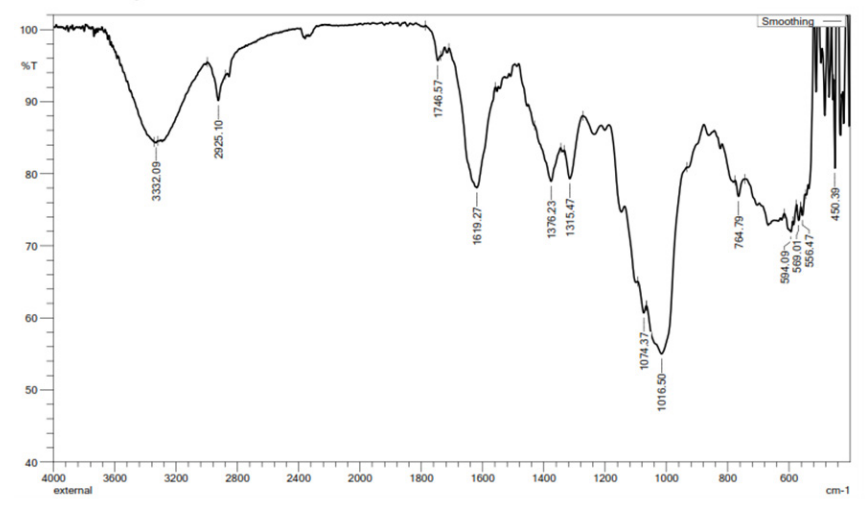

Figure 2: FTIR of functional groups present in Banana pith.
7. Ndabigengesere A, SubbaNarasiah K, Talbot BG. Active agents and mechanism of coagulation of turbid waters using Moringaoleifera. Water Res 1995; 29:703-710.

8. Saharudin NFAB, Nithyananda R. Wastewater treatment by using natural coagulant. $2^{\text {nd }}$ eureka. 2014; 2-3.

9. Navin PK, Kumar S, Mathur M. Textile wastewater treatment: A critical review. Int J Eng Res Tech 2018; 6(11):1-7.

10. Verma AK, Dash RR, Bhunia P. A reviews on chemical coagulation/flocculation technologies for removal of color from textile wastewaters. J Envt Manage 2012;93:154-168.

11. Vijayaraghavan G, Kumar PV, Chandrakanthan K, Selvakumar S. Acanthocereus tetragonus an effective natural coagulant for the Decolorization of synthetic dye wastewater. J Mat Envt Sci 2017;8(9):3028-3033.

12. Suryawan WK, Helmy Q, Notodarmojo S. Textile wastewater treatment: color and COD removal of reactive black- 5 by ozonation. Ear Env Sci 2018;106:12102.

13. Kizhakedathil MPJ, Sinha P, Mahuwala AA, Subramanian S. In-vitro Hemolytic and Clot Buster Activity of the Extracts of Ananas Comosus (Pineapple). Int J Pharm Sci Rev Res 2016;41(44):239-243.

14. Kizhakedathil MPJ, Ali MA, Vishnu H, Shylaja G, Mythili S, Sathiavelu A. Evaluation of antibacterial and antioxidant activity of Garcinia gummigutta. Int J Drug Devp Res 2015;7:57-59.

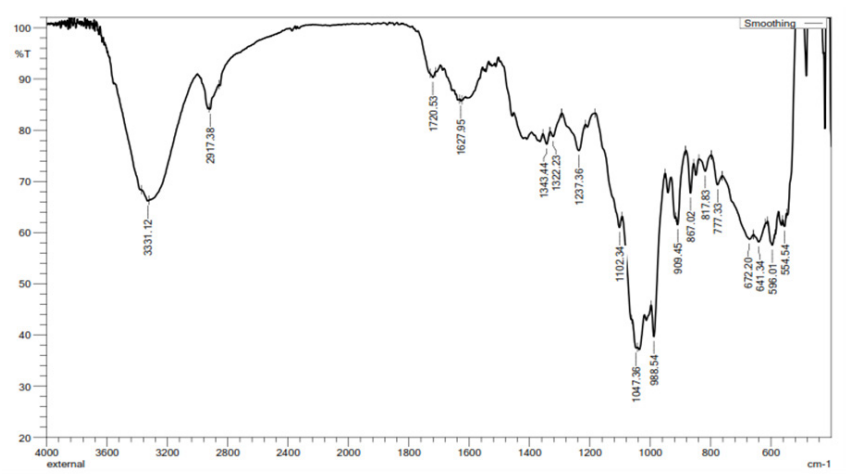

Figure 3: FTIR of functional groups present in Pineapple peel.

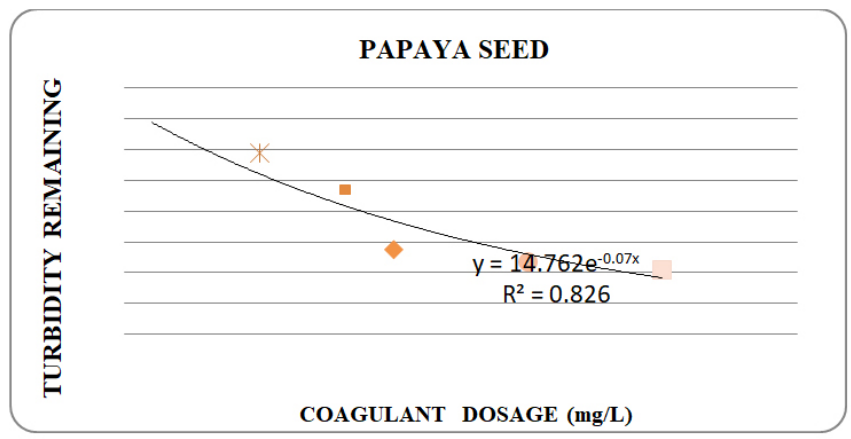

Figure 4: Graphical representation of turbidity remaining against coagulant dosage of papaya seed powder. 


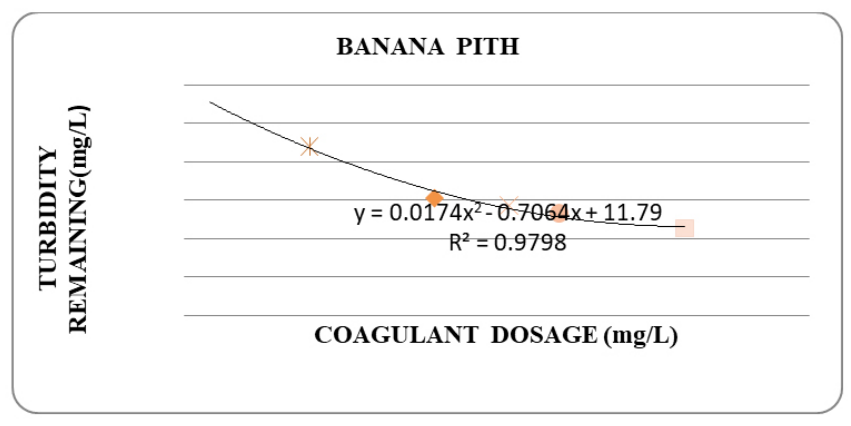

Figure 5: Graphical representation of turbidity remaining at various coagulant dosages using Banana pith powder.

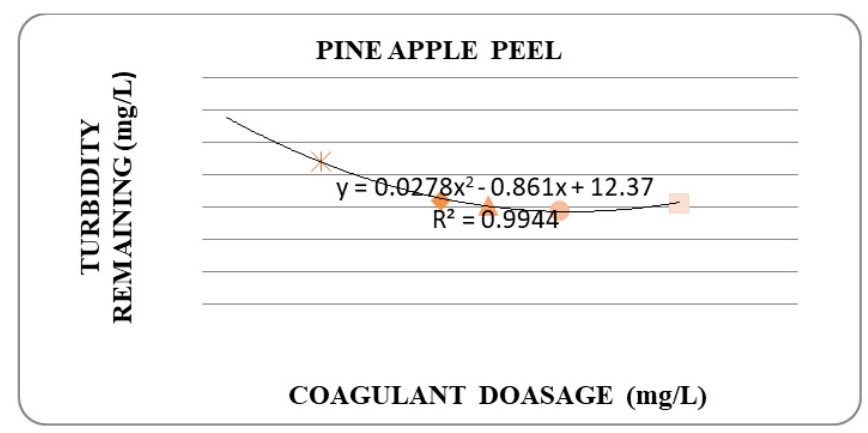

Figure 6: Graphical representation of turbidity remaining against coagulant dosage of Pineapple peel powder.

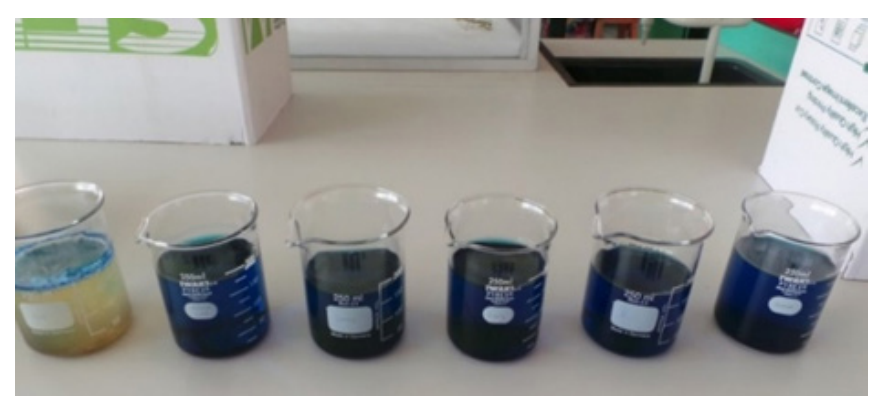

Figure 7: Presence of brownish precipitate in treated wastewater.

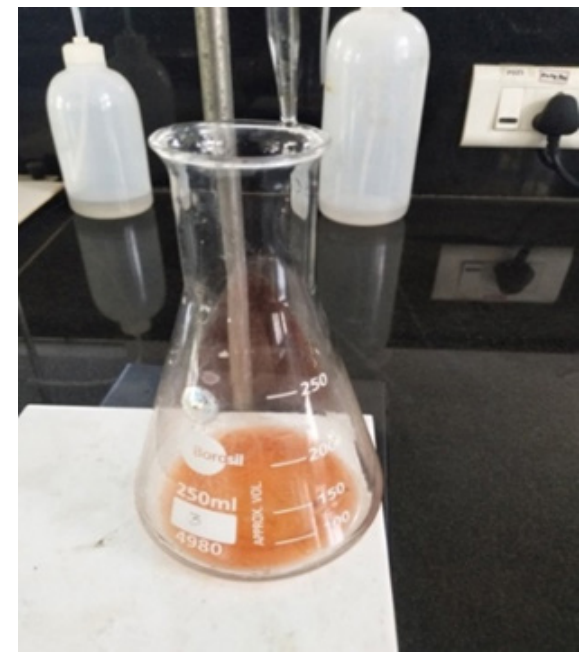

Figure 8: Formation of brown precipitate in treated wastewater.

Table 1: Turbidity removal composition of papaya seed, banana pith and pineapple peel powders at various coagulant dosages

\begin{tabular}{lcccc} 
S.no & $\begin{array}{c}\text { X (Coagulant } \\
\text { dosage) } \mathrm{mg} / \mathrm{L}\end{array}$ & \multicolumn{3}{c}{ Y (Turbidity remaining) } \\
Papaya & $\begin{array}{c}\text { Banana } \\
\text { seed }\end{array}$ & $\begin{array}{c}\text { Pineapple } \\
\text { peel }\end{array}$ \\
\hline 1. & 5 & 11.8 & 8.8 & 8.8 \\
2. & 8 & 9.6 & 6.1 & 6.4 \\
3. & 10 & 5.5 & 5.7 & 6.1 \\
4. & 15 & 4.7 & 5.3 & 5.8 \\
5. & 20 & 4.2 & 4.35 & 6.25 \\
\hline
\end{tabular}

Table 2: Titration readings and its end product $\%$ based on treated waste water sample

\begin{tabular}{llcccl}
\hline $\begin{array}{l}\text { S. } \\
\text { No }\end{array}$ Raw water & \multicolumn{2}{c}{$\begin{array}{l}\text { Titration } \\
\text { readings } \\
\text { sample }\end{array}$} & $\begin{array}{l}\text { initial } \\
\text { final }\end{array}$ & difference & $\begin{array}{l}\text { Indica- } \\
\text { tion end } \\
\text { point }\end{array}$ \\
1. $\quad \begin{array}{l}\text { Untreated } \\
\text { waste water }\end{array}$ & 0 & 2.3 & 89.06 & Red color \\
2. $\begin{array}{l}\text { Treated } \\
\text { waste water }\end{array}$ & 2.3 & 4.7 & 51.26 & Red color \\
\hline
\end{tabular}

